\title{
KONSEP GUGATAN PEMERINTAH ATAS PENCEMARAN \\ LINGKUNGAN: KOMPARASI ANTARA INDONESIA DAN \\ AMERIKA SERIKAT
}

\author{
Dona Pratama Jonaidi \\ Andri G. Wibisana \\ Analis Hukum Badan Pusat Statistik \\ Guru Besar Fakultas Hukum Universitas Indonesia \\ Email: donajonaidi@gmail.com; andri.gunawan@ui.ac.id
}

\begin{abstract}
In recent years, the Minister of Environment and Forestry (MoEF) has intensified the use of its rights to sue for environmental damage. In most of the lawsuits, the courts have ruled in favor of the MoEF. Surprisingly, hitherto no restoration has taken place in areas where the MoEF's claims for damages have been granted. Based on conceptual and comparative approaches, this research addresses the restoration of environmental damage in the United States of America and Indonesia. This article finds some problems with the restoration of environmental damage in Indonesia, such as the absence of a Recovery Plan, the use of theoretical damage valuation methods, and the absence of full compensation measures. This article also proposes some recommendations to improve the implementation of the government's right to sue in Indonesia.
\end{abstract}

Key words: government's right to sue, environmental damage, restoration.

\begin{abstract}
Abstrak
Dalam beberapa tahun terakhir, Menteri Lingkungan Hidup dan Kehutanan (LHK) telah meningkatkat penggunaan hak gugat pemerintah untuk kerugian lingkungan. Hampir semua gugatan tersebut dimenangkan oleh Menteri LHK. Namun, hingga saat ini, ternyata belum ada tindakan pemulihan apapun yang dilakukan pemerintah, termasuk di daerah yang gugatan atas pemulihan telah dimenangkan oleh pemerintah. Dengan menggunakan pendekatan konseptual dan komparatif, penelitian ini membahas pemulihan lingkungan di Amerika Serikat dan Indonesia. Studi ini menemukan sejumlah masalah mengenai pemulihan lingkungan di Indonesia, di antaranya adalah tidak adanya Rencana Pemulihan, penggunaan metode penilaian pencemaran yang bersifat teoretis, dan kompensasi yang tidak penuh atas kerugian lingkungan. Tulisan ini juga memberikan beberapa usulan bagi perbaikan hak gugat pemerintah di Indonesia.
\end{abstract}

Kata kunci: hak gugat pemerintah, kerugian lingkungan, pemulihan. 


\section{Latar Belakang}

Gugatan pemerintah atas pencemaran dan/ atau kerusakan ${ }^{1}$ lingkungan merupakan hal yang lazim dewasa ini. Masifnya pencemaran terhadap sumber daya alam yang sebagian besar disebabkan oleh aktivitas manusia dan meningkatnya kesadaran akan berharganya nilai lingkungan menjadi dua faktor penting untuk memperhitungkan peran negara dalam persoalan atas kerugian lingkungan. Negara tidak hanya menempati posisi sebagai wasit, yakni berperan sebagai regulator dan supervisor terhadap suatu sumber daya alam, namun juga perlu terlibat secara aktif dalam upaya pemulihan atas rusak atau musnahnya sumber daya alam tersebut, di antaranya melalui gugatan terhadap pencemar untuk bertanggung jawab atas kerugian lingkungan yang telah disebabkannya. Dalam hukum ini dikenal sebagai hak gugat pemerintah. ${ }^{2}$

Di Indonesia, gugatan pemerintah atas pencemaran lingkungan telah telah diatur sejak diberlakukannya Undang-Undang Nomor 4 Tahun 1982 tentang Ketentuanketentuan Pokok Pengelolaan Lingkungan Hidup (UU KPPLH). ${ }^{3}$ Pengaturan tersebut dipertegas kembali dalam Undang-Undang Nomor 23 Tahun 1997 tentang Pengelolaan Lingkungan Hidup (UU PLH). ${ }^{4}$ Terakhir, hak gugat pemerintah dimuat dalam UndangUndang Nomor 32 Tahun 2009 tentang Perlindungan dan Pengelolaan Lingkungan Hidup (UU PPLH). ${ }^{5}$

Dalam implementasinya, kedudukan pemerintah telah diakui eksistensinya, baik oleh pengadilan maupun pihak tergugat yang

1 Guna mempersingkat penulisan, kecuali jika merujuk pada peraturan perundang-undangan, untuk selanjutnya istilah yang akan digunakan untuk "pencemaran dan/atau kerusakan" adalah "pencemaran".

2 Pendekatan pengaturan (regulatory approach) atau Command and Control (CAC) yang secara tradisional diandalkan untuk mengatasi pencemaran ternyata memiliki beberapa kelemahan sehingga perlu diatasi dengan melibatkan pendekatan ekonomi (economic-incentives approach) seperti environmental taxes dan emission trading. Beberapa kritik terhadap CAC tersebut dapat diringkas sebagai berikut: i) CAC sangat fokus pada sistem perizinan yang mana seringkali mengabaikan dampak buruk dari kualitas lingkungan; ii) CAC membutuhkan biaya informasi dan pencegahan yang tinggi; iii) pendekatan CAC dalam banyak kasus gagal menghasilkan insentif yang memadai bagi pencemar untuk mengurangi tingkat polusi mereka; iv) pendekatan CAC seringkali terlalu umum dan tidak spesifik sehingga memukul rata standar regulasi untuk semua pencemar; v) dalam pendekatan CAC para pencemar hanya akan membayar biaya-biaya pencegahan yang diwajibkan untuk mengikuti standar aturan, bukan atas dasar polusi yang mereka hasilkan. Michael Faure et al., "Economic instruments : suited to developing countries ?," in Environmental Law in Development: Lessons from the Indonesian Experience, edited by Michael Faure and Nicole Niessen (Cheltenham: Edward Elgar Publishing, 2006), pp. 222-224.

3 Pasal 20 ayat (3) UU KPPLH menentukan bahwa, "Barangsiapa merusak dan/atau mencemarkan lingkungan hidup memikul tanggung jawab membayar biaya-biaya pemulihan lingkungan hidup kepada negara."

Pada Penjelasannya disebutkan bahwa besar biaya pemulihan ditetapkan oleh suatu tim yang khusus dibentuk oleh pemerintah. Tim tersebut melakukan penelitian yang meliputi bidang ekologi, medis, sosial budaya, dan lain-lain yang diperlukan.

4 Pada Pasal 37 ayat (2) dan (3) UU PLH secara eksplisit dinyatakan bahwa, "Jika diketahui bahwa masyarakat menderita karena akibat pencemaran dan/atau perusakan lingkungan hidup sedemikian rupa sehingga mempengaruhi perikehidupan pokok masyarakat, maka instansi pemerintah yang bertanggung jawab di bidang lingkungan hidup dapat bertindak untuk kepentingan masyarakat."

5 Pasal 90 ayat (1) UU PPLH memuat ulang ketentuan gugatan pemerintah dengan rumusan sebagai berikut: "Instansi pemerintah dan pemerintah daerah yang bertanggung jawab di bidang lingkungan hidup berwenang mengajukan gugatan ganti rugi dan tindakan tertentu terhadap usaha dan/atau kegiatan yang menyebabkan pencemaran dan/atau kerusakan lingkungan hidup yang mengakibatkan kerugian lingkungan hidup.” 
diduga melakukan pencemaran lingkungan. Sebagian besar, perdebatan lebih terfokus pada pertanyaan apakah pemerintah pusat dan pemerintah daerah harus mengajukan gugatan secara bersama-sama atau dapat dilakukan terpisah. ${ }^{6}$ Perdebatan lainnya adalah mengenai bagaimana pemulihan kerugian lingkungan yang didalilkan oleh pemerintah dalam gugatannya, utamanya mengenai penghitungan kerugian.

Hampir dalam setiap persidangan, kalau tidak dapat disebut selalu, objektivitas dan validitas penilaian kerugian yang dilakukan oleh pemerintah disangsikan. Indonesia pula diduga masih tertahan pada pendekatan penghitungan kerugian yang bersifat konvensional monetary valuation yang dinilai kurang mampu memulihkan lingkungan yang rusak dan/atau tercemar serta kerugian yang timbul karenanya secara maksimal. ${ }^{7}$ Lebih dari semua itu, hingga hari ini tercatat belum ada pemulihan apapun yang dilakukan dari sejumlah gugatan pemerintah yang telah dikabulkan oleh pengadilan. ${ }^{8}$

Tulisan ini bermaksud melihat kembali bagaimana hak gugat pemerintah diimplementasikan di Indonesia, dan bagaimana implementasi ini jika dibandingkan dengan praktik di Amerika Serikat (AS). Tulisan ini menyadari bahwa Indonesia bukanlah negara pertama yang menerapkan gugatan pemerintah atas pencemaran. Berdasarkan pada alasan tersebut, tulisan ini mengulas praktek hak gugat pemerintah di AS sebagai negara pioneer yang menetapkan ketentuan pertanggungjawaban atas lingkungan (environmental liabilty). ${ }^{9}$ Selain itu, banyak prinsip-prinsip dalam ketentuan pertanggungjawaban lingkungan di AS telah diadopsi oleh negara-negara di dunia. $^{10}$

6 Permasalahan hal tersebut telah diselesaikan oleh Peraturan Ketua Mahkamah Agung Nomor 036/KMA/2013 tentang Pemberlakuan Pedoman Penanganan Perkara Lingkungan Hidup.

7 Faure dan Liu menyimpulkan secara singkat bahwa, "Thus for natural resources that are more valuable ecologically than economically, the most effective remedy is restoration, not monetary compensation. Compensation instruments for natural resources damage are best structured so as to finance and promote restoration, rather than merely providing monetary compensation. Both the United States and European counties adopt this restoration-based approach." (Michael Faure and Jing Liu, "New Models For The Compensation Of Natural Resources Damage," Kentucky Journal for Equine, Agriculture, and Natural Resources Law 4, No. 2 (2012): 269).

8 Berdasarkan keterangan dari Kepala Sub Direktorat Penyelesaian Sengketa Lingkungan Hidup Melalui Pengadilan Pada Direktorat Penyelesaian Sengketa Lingkungan Hidup pada wawancara yang dilakukan pada tanggal 14 Oktober 2019 didapati bahwa hingga akhir tahun 2019, pemerintah Indonesia yang diwakili oleh Kementerian Lingkungan Hidup dan Kehutanan (KLHK) telah mengajukan sebanyak 22 gugatan, dengan rincian 11 gugatan yang telah memperoleh kekuatan hukum tetap dan 11 lainnya masih dalam tahap persidangan. Telah terdapat dua tergugat yang melakukan pembayaran biaya pemulihan dan/atau biaya ganti rugi atas kerusakan ekosistem ke Kas Negara, yakni PT. Bumi Mekar Hijau dan PT. Selatnasik Indokwarsa/PT. Simpang Pesak Indokwarsa.

9 Carol Adaire Jones et al., "Tropical Conservation and Liability for Environmental Harm," Environmental Law Review 45, No. 1 (2015): 1035.

10 Di antara yang mengadopsi prinsip-prinsip pertanggungjawaban atas kerugian lingkungan sebagaimana yang diterapkan oleh AS adalah Uni Eropa. Melalui Europen Union's Environmental Liability Directive (ELD) tahun 2004 yang prinsip-prinsip pertanggungjawaban (liability) diintegrasikan ke dalam undang-undang negara anggota Uni Eropa pada tahun 2010. (Jacob Phelps et.al., "Liability for Environmental Harm as a Response to the Anthropocene," in Charting Environmental Law Futures in the Anthropocene, ed. oleh Michelle Lim (Singapore: Springer, 2019), p. 173). 
Dengan perbandingan ini, tulisan ini akan memperlihatkan konsekuensi teoretis dan praktis dari perbedaan implementasi hak gugat pemerintah di Indonesia dan AS. Dari perbandingan, tulisan ini melihat bahwa hak gugat pemerintah di Indonesia tidak pernah dibarengi dengan adanya rencana pemulihan, sebagai dasar penentuan besaran ganti rugi. Akibatnya, bukan hanya penghitungan didasarkan pada metode yang bersifat hipotetis, tetapi juga pada akhirnya tidak ada jaminan bahwa pemerintah akan menggunakan uang yang diperoleh dari penggunaan hak gugatnya akan dipakai untuk melakukan pemulihan.

Setelah Pendahuluan, Bagian B akan memperlihatkan landasan hukum dan praktik penggunaan hak gugat pemerintah di AS, dengan mengaitkan kedua hal tersebut dengan pemulihan lingkungan. Berbagai konsep penting, seperti primary restoration atau compensatory restoration akan dibahas dalam Bagian ini.

Selanjutnya, Bagian C akan memperlihatkan bagaimana hak gugat Pemerintah di Indonesia. Bagian ini bukan hanya menjelaskan landasan hukum hak gugat pemerintah, yaitu Pasal90UUPPLH, tetapijuga mendiskusikan bagaimana kerugian dihitung dan dieksekusi di Indonesia. Bagian D akan menjelaskan missing-links yang menjelaskan keterkaitan antara hak gugat, penghitungan kerugian, dan pemulihan. Bagian ini juga akan menjelaskan secara singkat rekomendasi untuk mengatasi kekurangan teoretis dan praktis yang ada dalam hak gugat Pemerintah di Indonesia. Bagian E secara singkat akan memberikan uraian penutup.

\section{Pembahasan}

\section{A. Konsep Pemulihan Kerugian Lingkungan di AS}

Dalam berbagai literatur dan peraturan di AS, ganti rugi untuk kerugian lingkungan didefinisikan sebagai ganti rugi sumber daya alam (natural resource damage, NRD). Ganti rugi ini dianggap berbeda dari ganti rugi lingkungan melalui pertanggungjawaban perdata, dan berbeda pula dari denda atau ongkos pemulihan berupa biaya pembersihan dan remediasi (cleanup costs and remediation). ${ }^{11} \quad$ Kebutuhan akan pengaturan mengenai NRD muncul karena pertanggungjawaban perdata biasa atau pembersihan dan remediasi seringkali dianggap tidak mencukupi untuk mengganti kerugian yang muncul pada lingkungan hidup atau sumber daya alam. ${ }^{12}$

11 Karen Bradshaw, "Settling for Natural Resource Damages", Harvard Environmental Law Review, Vol. 40, (2016): 219.

12 Lihat, misalnya pandangan Gray yang menyatakan bahwa upaya pemulihan melalui remedial action sering kali tidak mencukupi dan benar-benar mampu memulihkan lingkungan yang tercemar. Sementara itu, dengan merujuk pada pandangan pengadilan dalam Ohio v. DOI, Mazzottaa, dkk menyatakan bahwa pengaturan mengenai NRD salah satunya muncul karena kekecewaan terhadap kemampuan pertanggungjawaban perdata, common law remedies, terkait ganti rugi lingkungan. Lihat: Peter L. Gray, The Superfund Manual: A Practitioner's Guide to CERCLA Litigation, (Chicago: ABA, 2016), p. 297; dan Marisa J. Mazzotta et.al., "Natural Resource Damage Assessment: The Role of Resource Restoration," Natural Resources Journal, Vol. 34 (Winter 1994): 155. 
Pemulihan kerugian lingkungan di AS didasarkan pada berbagai undang-undang Federal, dua yang terpenting adalah CERCLA (Comprehensive Environmental Response, Compensation, and Liability Act) dan OPA (Oil Pollution Act). ${ }^{13}$ CERCLA dan OPA memberikan wewenang kepada pemerintah federal, pemerintah negara bagian, dan Indian tribe untuk bertindak sebagai wali (trustee) atas rusak atau musnahnya sumber daya alam yang dimiliki, dikelola, dikontrol, atau terkait dengannya. OPA bahkan juga mengizinkan pemerintah negara asing untuk menjadi trustee sehubungan dengan rusaknya atau hilangnya sumber daya alam yang dimiliki, dikelola, dikontrol, atau terkait dengannya. ${ }^{14}$

Setiap wali ini memiliki dua fungsi. Pada satu sisi, wali harus melakukan penilaian atas kerugian lingkungan yang terjadi untuk sumber daya yang berada di dalam mandatnya. Pada sisi lain, wali juga harus membuat dan menerapkan rencana untuk memulihkan, merehabilitasi, mengganti, atau memperoleh sumber daya lain yang sebanding dengan, lingkungan yang rusak yang berada di dalam kewenangannya. Khusus untuk pemerintah Federal, mereka juga dapat melakukan penilaian atas permintaan negara bagian atau suku Indian. ${ }^{15}$

Pada dasarnya, objek perwalian (trust corpus) pemerintah hanya meliputi sumber daya alam yang tidak dimiliki oleh siapa pun (public natural resources). Namun dalam perkembangannya, di bawah CERCLA dan OPA pemerintah telah pula berwenang untuk bertindak sebagai wali terhadap sumber daya alam yang dimiliki oleh privat (privatelyowned natural resources) ${ }^{16}$ Menurut CERCLA dan OPA pemerintah dapat memulihkan kerugian untuk rusaknya terhadap sumber daya alam yang terkait dengannya melalui kepemilikan, pengelolaan, perwalian, dan kontrol. ${ }^{17}$ Karena itu, apabila pemerintah memiliki " $a$ substantial degree of control" atas sumber daya alam yang dimiliki oleh privat, peraturan terkait pemulihan kerugian lingkungan dari

13 CERCLA diundangkan pada tahun 1980 dan diamandemen oleh Superfund Amendments and Reauthorization Act tahun 1986 sehingga ia dikenal juga dengan sebutan Superfund. CERCLA dibentuk untuk memberikan pengaturan perihal pertanggungjawaban (liability), kompensasi/ganti rugi (compensation), pembersihan (cleanup), dan respon darurat (emergency response) ketika materi-materi berbahaya dilepaskan ke lingkungan, dan terkait pembersihan lokasi pembuangan limbah. Sementara itu, OPA diundangkan sebagai respon atas peristiwa tumpahan minyak Exxon Valdez di Alaska tahun 1989 dan peristiwa besar serupa lainnya seperti inseden the American Trader di California tahun 1990 dan the World Prodigy di Rhode Island di tahun yang sama.CERCLA dan OPA bukanlah undang-undang federal pertama yang memberikan wewenang kepada instansi pemerintah tertentu untuk melakukan pemulihan atas kerugian lingkungan. Sebelumnya telah ada beberapa undang-undang lainnya yang membentuk cause of action untuk memulihkan kerugian yang timbul akibat kerusakan terhadap sumber daya alam tertentu, seperti the Deep Water Port Act of 1974, the Federal Water Pollution Act (Clean Water Act), the Trans-Alaska Pipeline Authorizatin Act of 1973 (TAPA), the Outer Continental Shelf Lands Act of 1978, dan the National Sanctuaries Act of 1988. Beberapa konten di undangundang tersebut bahkan hampir identik sebagaimana yang terdapat pada CERCLA dan OPA. Selain itu, pemulihan kerugian lingkungan di AS juga diatur oleh undang-undang negara bagian.

1442 U.S.C. § 9607 (f) (1); 33 U.S.C. § 2706 (a) (1) (2).

1533 U.S.C. $\$ 2706$ (c).

16 Edward H.P. Brans, Liability for Damage to Public Natural Resources: Standing, Damage and Damage Assessment (The Hague: Kluwer Law International, 2001), p. 83.

1742 U.S.C. $\$ 9601$ (f) (1); 33 U.S.C. § 2706 (a). 
CERCLA dan OPA akan dapat diterapkan terhadap properti privat tersebut. ${ }^{18}$

Undang-undang yang mengatur mengenai perlindungan lingkungan di AS (termasuk CERCLA maupun OPA) didesain untuk mencapai tujuan utama, yakni "make the public whole". ${ }^{19}$ Phelps, Jones, dan Pendergrass bahkan menyebut "make the public whole" sebagai prinsip yang mendasari gugatan publik (oleh pemerintah) maupun privat, dengan maksud untuk membantu pihak-pihak yang dirugikan kembali ke keadaan mereka seperti sebelum terjadinya pencemaran. ${ }^{20}$

Untuk mencapai tujuan tersebut CERCLA dan OPA secara progresif melampaui batasbatas tradisional dalam klaim ganti rugi yang mengharuskan kerusakan fisik terhadap kepentingan kepemilikan privat dan terbatas pada kerugian finansial saja, seperti kerugian properti, kerugian laba atau upah, atau dalam beberapa kasus terkait biaya penggantian. ${ }^{21}$ Di bawah CERCLA dan OPA, wali diberikan peluang menerapkan metode penilaian non-pasar selain menggunakan ukuranukuran ganti rugi yang berbasis penilaian pasar (market-based measures) untuk menilai kerusakan pada sumber daya alam.22 Penilaian kerugian dengan nilai pasar dipandang tidak dapat menangkap seluruh nilai yang diperoleh dari suatu sumber daya. ${ }^{23}$

Selain itu, pemulihan (restorasi) menjadi preferensi utama dalam klaim ganti rugi atas kerusakan/pencemaran trust corpus. Hal itu sebagaimana ditegaskan Pengadilan DC Circuit dalam State of Ohio v. DOI yang merujuk pada ketentuan dalam CERCLA yang menyatakan bahwa ganti kerugian yang diperolah wali hanya dapat digunakan untuk pemulihan, "for use only to restore, replace, or acquire the equivalent of such natural resources". ${ }^{24}$ Pengadilan juga merujuk pada ketentuan CERCLA yang sama bahwa ganti kerugian tidak hanya terbatas pada biaya pemulihan, "[t]he measure of damages ...shall not be limited by the sums which can be used to restore or replace such resources." 25 Dengan bahasa CERCLA yang

18 Brans, op.cit., p. 86. Diskusi mengenai apakah wali memiliki wewenang untuk memulihkan kerugian lingkungan terhadap sumber daya alam yang dimiliki oleh privat telah dimuat dalam putusan kasus State of Ohio v. U.S. Dept. of the Interior. (State of Ohio v. DOI, 880 F.2d 432, 459-461 (D.C. Cir. 1989)). Lihat pula: Carter H. Strickland, "The Scope of Authority of Natural Resource Trustees," Colombia Journal of Environmental Law 20, No. 1 (1995): 301-327.

19 Allan Kanner, "Natural Resource Restoration," Tulane Environmental Law Journal 28, No. 1 (2015): 5.

20 Phelps et.al., op.cit.: 173.

21 Carol Adaire Jones, "Economic Valuation of Resource Injuries in Natural Resource Liability Suits," Journal of Water Resources Planning and Management 126, No. 6 (2000): 358.

22 Ibid.

23 Pengadilan D.C. Circuit dalam State of Ohio v. DOI menolak ketentuan dari peraturan penilaian kerugian lingkungan yang diterbitkan oleh The U.S. Department of the Interior tahun 1986 yang mengutamakan penggunaan metode penilaian pasar dalam penilaian kerugian lingkungan dan menentukan bahwa metode penilaian non-pasar baru dapat digunakan apabila metode pasar dinilai tidak cukup kompetitif dalam menakar kerugian. Sebaliknya, menurut pengadilan, pembentuk undang-undang (Congress) bermaksud agar peraturan penilaian kerugian lingkungan untuk menangkap sepenuhnya semua aspek kerugian. (State of Ohio v. DOI, 880 F.2d 432, 463 (D.C. Cir. 1989)).

2442 U.S.C. $\S 9607$ (f) (1).

2542 U.S.C. $\S 9607$ (f) (1). 
jelas tersebut, Pengadilan menilai bahwa CERCLA menginginkan pemulihan sebagai dasar dari penghitungan kerugian, meskipun ganti kerugian di luar biaya pemulihan masih sangat dimungkinkan. ${ }^{26}$

Titik tekan pada pemulihan juga tercermin dari pengaplikasian konsep "full compensation" di AS. Di bawah CERCLA dan OPA wali diizinkan memulihkan kerugian lingkungan melalui klaim ganti rugi yang terdiri dari dua komponen utama, yaitu biaya memulihkan sumber daya yang rusak ke kondisi dasar (cost for primary restoration) dan kompensasi untuk hilangnya sementara sumber daya dari saat kejadian hingga pulih sepenuhnya (compensation for interim losses/ compensable value). ${ }^{27}$ Bersamaan dengan itu, wali dapat meminta penggantian atas biaya-biaya yang telah dikeluarkannya dalam melakukan penilaian terhadap kerugian, misalnya biaya ahli, laboratorium, dan lainlain (reasonable cost of assessing damages). ${ }^{28}$

Grafik berikut akan menunjukkan hubungan antara tindakan pemulihan primer (primary restoration) dan pemulihan kompensasi atas kerugian sementara (compensatory restoration) sehingga kerugian yang diderita publik dapat sepenuhnya dipulihkan. Jika terjadi pencemaran, nilai jasa lingkungan turun dari baseline service level ke kondisi setelah pencemaran, yaitu garis putus-putus tunggal. Jones dan Di Pinto menjelaskan grafik tersebut dengan mengambil contoh kerusakan terhadap lahan basah (wetland) akibat tumpahan minyak. ${ }^{29}$ Turun/berkurangnya sumber daya ini lah yang harus dikembalikan, yang disebut dengan pemulihan primer (primary restoration). Terdapat dua pilihan primary restoration yang dapat dilakukan untuk memulihkan lahan basah yang tercemar, yaitu active restoration (misalnya, revegetasi) atau pemulihan secara alami (natural restoration). Dalam hal tindakan pemulihan primer (primary restoration) yang diambil adalah revegetasi, hal tersebut diproyeksikan dapat mempercepat dan/atau meningkatkan kemungkinan pemulihan sebagaimana pada $t_{1}$.

Selain dari pemulihan utama ini, dari gambar juga terlihat adanya kerugian yang muncul mulai dari saat kerusakan terjadi sampai dengan pemulihan berhasil dilaksanakan. Kerugian ini yang disebut dengan interim losses, kerugian sementara.

26 Pengadilan DC Circuit menyatakan,"This provision obviously reflects Congress apparent concern that its restorative purpose for imposing damages not be construed as making restoration cost a damages ceiling. But the explicit command that damages "shall not be limited by" restoration costs also carries in it an implicit assumption that restoration cost will serve as the basic measure of damages in many if not most CERCLA cases. It would be markedly inconsistent with the restorative thrust of the whole section to limit restoration based damages, as Interior's rule does, to a minuscule number of cases where restoration is cheaper than paying for lost use - [catatan kaki diabaikan]." Lihat: State of Ohio v. DOI, 880 F.2d 432, 445-446 (DC Cir., 1996).

2743 C.F.R. $\S 11.83$ (a) (1); 15 CFR $\S 990.30$.

2842 U.S.C. $\S 9607$ (a) (4) (C); 33 U.S.C. $\$ 2706$ (d) (1).

29 Carol Adaire Jones and Lisa DiPinto, "The Role of Ecosystem Services in USA Natural Resource Liability Litigation," Ecosystem Services 29 (2018): 336. 


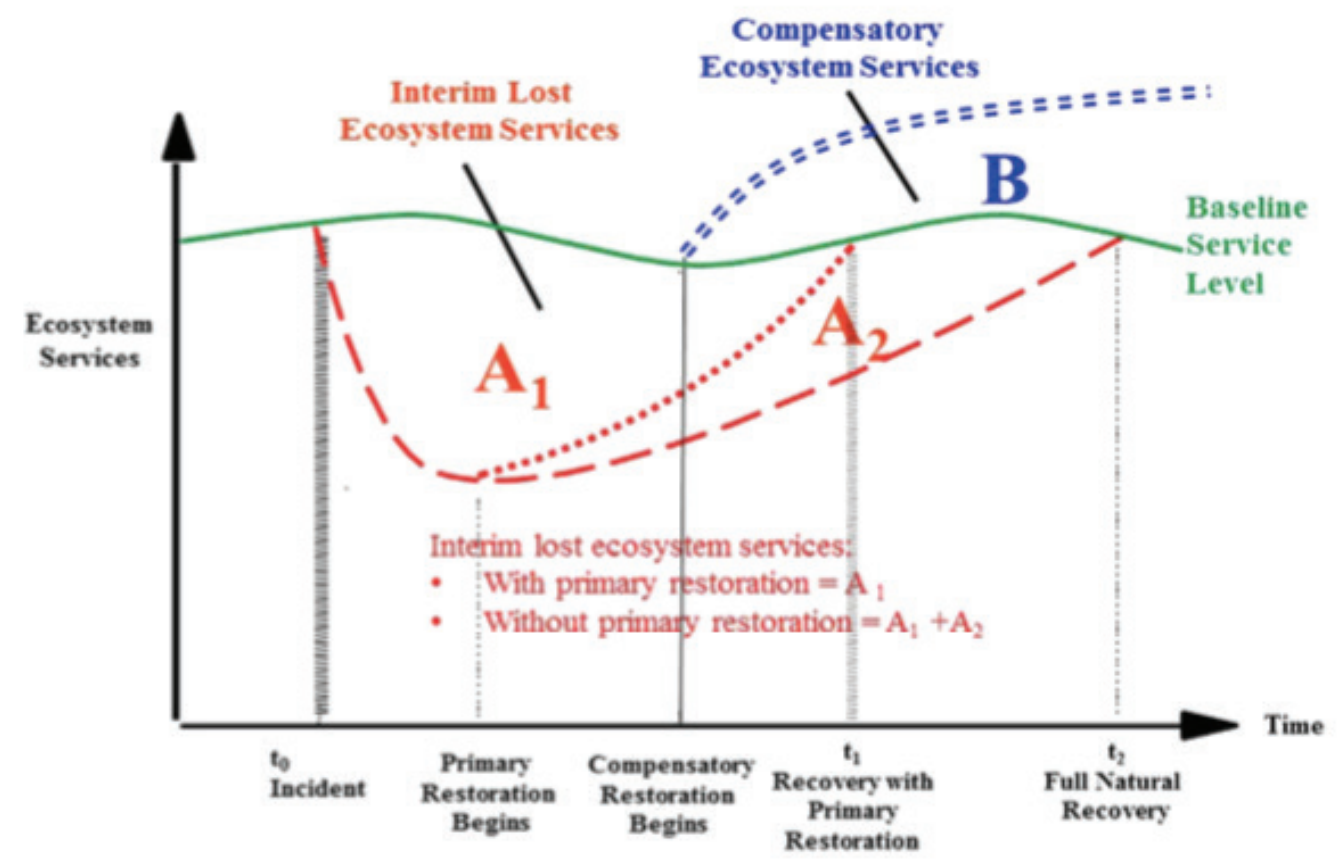

\section{Gambar 3.1. Hubungan antara Restorasi Primer dan Pemulihan Kompensasi}

Sumber: Carol Adaire Jones dan Lisa DiPinto, "The Role of ecosystem Services in USA

Natural Resource, Liability Litigation," Ecosystem Services 29 (2018): 338.

Kerugian ini pun harus dikompensasi. Nilai jasa yang hilang (interim losses) yang harus dikompensasi adalah seluas area $\mathrm{A}_{1}$, apabila pemulihan primer dilakukan secara aktif. Sementara itu, jika yang dipilih adalah pemulihan alami (natural restoration), lahan basah yang tercemar diproyeksikan akan kembali ke baseline level dalam waktu $t_{2}$ (lebih lama). Oleh karena itu, kompensasi terhadap interim losses meliputi nilai jasa pada area $\mathrm{A}_{1}$ $+\mathrm{A}_{2}$ (lebih banyak).

Perlu ditegaskan di sini bahwa gagasan kompensasi tidaklah selalu berupa uang (monetary compensation), tetapi juga dapat berupa berupa pemulihan atau penggantian sumber daya yang rusak (resource compensation). Dalam monetary compensation, ganti rugi dibayarkan dalam bentuk uang; maka dalam resource compensation, ganti rugi dilakukan dalam bentuk pemulihan primer ditambah dengan pemulihan tambahan (compensatory restoration). ${ }^{30}$ Di dalam Gambar 3.1, uang yang dibayar sebagai monetary compensation adalah sebanyak nilai yang hilang, yaitu $A_{1}$ untuk pemulihan aktif atau $\mathrm{A}_{1}+\mathrm{A}_{2}$ untuk pemulihan alamiah. Sedangkan resource compensation ditunjukkan sebagai pemulihan seluas area B. Metode yang lazim digunakan 
untuk resource compensation adalah Habitat Equivalency Analysis (HEA). ${ }^{31}$

Komitmen "make the public whole" dipertegas dengan ketentuan yang mewajibkan wali untuk menggunakan seluruh biaya ganti rugi yang diterimanya untuk kepentingan restorasi sebagaimana dinyatakan dalam rumusan CERCLA berikut ini:

"Sums recovered by the United States Government as trustee under this subsection shall be retained by the trustee, without further appropriation, for use only to restore, replace, or acquire the equivalent of such natural resources. Sums recovered by a State as trustee under this subsection shall be available for use only to restore, replace, or acquire the equivalent of such natural resources by the State. "'32
Penerapan konsep "full compensation" diimbangi dengan prosedur, di mana wali wajib mengidentifikasi dan mempertimbangkan sejumlah alternatif pemulihan yang dapat memulihkan atau mengganti sumber daya yang rusak dan jasa yang hilang kepada kondisi dasar mereka. ${ }^{33}$ Ketika memilih alternatif pemulihan yang paling tepat, sejumlah kriteria harus dipertimbangkan oleh wali, di antaranya: kelayakan teknis dari alternatif pemulihan (mungkin atau tidak mungkin dilakukan), efektivitas biaya, pertimbangan biaya-manfaat, kemampuan sumber daya alam untuk pulih tanpa tindakan apa pun, lamanya periode pemulihan alami dan hilangnya layanan publik selama periode itu, dan potensi kerusakan tambahan yang diakibatkan dari tindakan yang diusulkan. ${ }^{34}$

31 HEA adalah metode pendekatan penggantian jasa untuk menentukan sumber daya tambahan yang diperlukan untuk mengganti kerugian lingkungan yang sifatnya sementara. Setidaknya terdapat empat tahapan bagi penerapan HEA. Pertama, pemerintah (trustee) melakukan penaksiran seberapa lama terjadinya kerugian lingkungan, dari mulai munculnya kerugian sampai dengan waktu yang diperkirakan agar lingkungan menjadi pulih kembali. Kedua, pemerintah menentukan nilai manfaat yang diperoleh dari upaya proyek pemulihan sumber daya tambahan (compensatory projects). Ketiga, pemerintah menentukan besaran sumber daya pengganti tambahan ini, yang besarannya harus sama dengan kerugian sementara (interim losses). Keempat, pemerintah menentukan biaya untuk menyediakan sumber daya tambahan ini. Lihat: Andri G. Wibisana, Penegakan Hukum Lingkungan Melalui Pertanggungjawaban Perdata, (Depok: BP-FHUI, 2017), hlm. 246-247. Untuk pengantar teknis mengenai HEA, lihat misalnya: Carol A. Jones and Katherine A. Pease, "Restoration-Based Compensation Measures in Natural Resource Liability Statutes," Contemporary Economic Policy15 (October 1997): 111-122; atau Joan P. Snyder and William H. Desvousges, "Habitat and Resource Equivalency Analyses in Resource Compensation and Restoration Decision Making," Natural Resources \& Environment 28 (Summer 2013): 3-7. Menurut Liu, Faure, dan Wang, kompensasi berupa pemulihan lingkungan (resource compensation) lebih diutamakan dibandingkan dengan metode lainnya (valuasi ekonomi). Hanya jika pemulihan tidak dapat dilaksanakan, maka kompensasi berdasarkan nilai valuasi ekonomi dapat dilakukan. Lihat: Liu Jing et.al., "Compensating for Natural Resource Damage Caused by Vessel-Induced Marine Oil Pollution: Comparing the International, U.S., and Chinese Regimes," Journal of Environmental Law \& Litigation 29 (2014): 150-151.

3242 U.S.C. $§ 9607$ (f) (1). Lihat pula rumusan serupa pada OPA yang berbunyi sebagai berikut: "Sums recovered under this Act by a Federal, State, Indian, or foreign trustee for natural resource damages under section 2702(b)(2)(A) of this title shall be retained by the trustee in a revolving trust account, without further appropriation, for use only to reimburse or pay costs incurred by the trustee under subsection (c) with respect to the damaged natural resources. Any amounts in excess of those required for these reimbursements and costs shall be deposited in the Fund." (33 U.S.C. § 2706 (f)).

3343 C.F.R. $\S 11.82$ (b).

3443 C.F.R. $\S 11.82(d)$. 
Di AS, perhitungan kerugian lingkungan dilakukan dalam beberapa tahapan. Berdasarkan The U.S. Department of the Interior's Natural Resource Damage Assessment Regulations (selanjutnya disebut Peraturan DOI) prosedur penghitungan kerugian lingkungan meliputi empat fase yang harus diikuti oleh wali, antara lain: i) Tahap Pra-Penghitungan (Preassessment Phase); ii) Tahap Perencanaan Penghitungan (Assessment Plan Phase); iii) Tahap Penghitungan berdasarkan peraturan Tipe A atau Tipe B (Assessment Phase based on type $A$ rule or type $B$ rule); dan iv) Tahap Pasca Penghitungan (Post-Assessment Phase). ${ }^{35}$ Sementara itu, di bawah ketentuan The National Oceanic and Atmospheric Administration 's Natural Resource Damage Assessment Regulations (selanjutnya disebut Peraturan NOAA) prosedur penilaian terhadap kerugian lingkungan dilakukan melalui tiga tahapan utama, antara lain: i) Tahap Pra-Penilaian (Pre Assessment Phase); ii) Tahap Perencanaan Restorasi (Restoration Planning Phase); dan iii) Tahap Implementasi Pemulihan (Restoration Implementation Phase). ${ }^{36}$

Komitmen memulihkan sumber daya alam secara penuh dapat jelas dilihat pada Tahap Penentuan Kerugian (Damage Determination
Phase). Peraturan DOI menentukan bahwa pejabat yang berwenang harus membuat beberapa alternatif yang dapat memulihkan (dalam arti restorasi atau rehabilitasi) dan menggantikan sumber daya yang rusak. ${ }^{37}$ Ketika memilih alternatif pemulihan atau penggantian, harus diperhatikan beberapa faktor, yaitu: fisibiliti secara teknis; hubungan antara biaya untuk melakukan tindakan pemulihan atau penggantian dengan manfaat yang diharapkan akan diperoleh dari tindakan tersebut; hasil dari respon yang telah dilakukan atau direncanakan; potensi munculnya kerusakan tambahan dari tindakan yang diusulkan, termasuk dampak jangka panjang dan dampak tidak langsung, terhadap sumber daya yang akan dipulihkan/diganti; pemulihan secara alamiah; potensi dampak terhadap kesehatan dan keamanan manusia; sejalan dan taat terhadap hukum yang berlaku. ${ }^{38}$

Pada Peraturan DOI ditentukan beberapa metode valuasi yang dapat digunakan dalam menghitung Compensable value, antara lain: Market price, Appraisal, Factor income atau disebut juga "reverse value added" methodology, Travel cost, Hedonic pricing, Unit value/benefits transfer, Contingent valuation ( $\mathrm{CV})$, Conjoint Analysis (CA), Habitat Equivalency Analysis (HEA), Resource Equivalency Analysis (REA), dan

35 Baca: Douglas D. Ofiara, "Natural Resource Damage Assessments in the United States: Rules and Procedures for Compensation from Spills of Hazardous Substances and Oil in Waterways under US Jurisdiction," Marine Pollution Bulletin 44, No. 2 (2002): 100. Tahapan serupa juga dijelaskan oleh Burlington seperti dapat dilihat pada: Linda B. Burlington, "Valuing Natural Resource Damages: A Transatlantic Lesson," Environmental Law Review 6, No. 2 (2004): 78-81.

3615 C.F.R. Part 990.

3743 C.F.R. $\S 11.82(1)$.

3843 C.F.R. $\S 11.82$ (d). 
Random Utility Model. ${ }^{39}$ Selain metode di atas, Peraturan DOI mengizinkan digunakannya metode lain untuk menghitung willingness to pay (WTP) dari masyarakat atas jasa lingkungan yang hilang atau menghitung biaya pemulihan atau penggantian, sepanjang metode tersebut merupakan metode yang dapat diterima untuk menentukan compensable value. $^{40}$

Sementara itu, Peraturan NOAA juga memuat beberapa ketentuan terkait pemulihan untuk mengganti kerugian sementara (interim losses). Peraturan NOAA mensyaratkan wali untuk mempertimbangkan berbagai tindakan yang dapat menyediakan jasa dengan tipe dan kualitas yang sama (same type and quality), serta memiliki nilai yang sebanding (comparable value) dengan sumber daya yang mengalami kerugian. Jika tindakan pemulihan yang ada tidak dapat menyediakan berbagai alternatif, wali mempertimbangkan berbagai alternatif lain yang mampu menyediakan sumber daya dan jasa yang memiliki tipe dan kualitas yang sebanding (comparable type and quality). Jika ternyata sumber daya yang rusak dan penggantinya tidak memiliki nilai yang sebanding, wali mempertimbangkan metode valuasi dalam penentuan skala. ${ }^{41}$
Sekalipun kedua peraturan tersebut memiliki pendekatan penilaian kerugian yang berbeda, di mana Peraturan DOI lebih menekankan pada penilaian kerugian dalam kerangka moneter (monetary framework) sementara pendekatan yang digunakan pada Peraturan NOAA fokus pada pendekatan restorasi (restoration approach), ${ }^{42}$ akan tetapi pada akhirnya kedua peraturan tersebut berujung pada muara yang sama, yakni dokumen rencana pemulihan (Restoration Plan). ${ }^{43}$ Restoration Plan harus menjelaskan bagaimana uang untuk biaya pemulihan (restoration costs) akan digunakan untuk menangani sumber daya alam yang tercemar dan/atau rusak dan Restoration Plan juga harus menggambarkan bagaimana uang ganti rugi (compensable value) akan digunakan untuk menangani jasa lingkungan yang hilang sejak terjadinya pencemaran hingga pemulihan selesai dilakukan. ${ }^{44}$

Regulasi di AS mengharuskan Restoration Plan memuat informasi-informasi terkait dengan: i) sejumlah kemungkinan alternatif untuk pemulihan dan/atau nilai yang dapat dikompensasi; ii) alternatif dan tindakan yang diperlukan untuk mengimplementasikan alternatiftersebut beserta alasan pemilihannya;

3943 C.F.R. $\S 11.83$ (c) (2) (i-xi).

4043 C.F.R. $\S 11.83$ (c) (3).

4115 C.F.R. $\$ 990.53$ (c).

42 Kanner dan Ziegler menyebut bahwa rezim NOAA "berbasis restorasi," yaitu menetapkan restorasi sumber daya alam yang rusak sebagai tujuannya dan memberikan lembaga dan pihak yang bertanggung jawab banyak fleksibilitas untuk mengembangkan rencana untuk bergerak maju dan mencapainya. (Allan Kanner and Mary E. Ziegler, "Understanding and Protecting Natural Resources," Duke Environmental Law \& Policy Forum 17 , No. 119 (2006): 147).

4343 C.F.R. $\S 11.91$ (a) (b); 15 C.F.R. $\S 990.55$.

4443 C.F.R. $\S 11.93$ (a). 
dan iii) metodologi yang akan digunakan untuk menentukan biaya dari alternatif pemulihan yang dipilih dan nilai kompensasi dari jasa lingkungan yang hilang. ${ }^{45}$ Di samping itu, ketika mengembangkan Rancangan Rencana Pemulihan, wali harus menetapkan tujuan pemulihan/restorasi yang spesifik atas pencemaran yang terjadi. Tujuan tersebut harus secara jelas menentukan hasil yang diinginkan serta kriterianya sehingga dapat dinilai bahwa restorasi telah berhasil dan dapat dinyatakan selesai. ${ }^{46}$

Restoration Plan menjadi dasar bagi wali untuk meminta pertanggungjawaban kepada pihak yang melakukan perusakan dan/atau pencemaran lingkungan (PRPS), antara lain untuk: i) mengimplementasikan Restoration Plan dengan tunduk pada pengawasan wali dan mengganti biaya yang telah dikeluarkan oleh wali untuk penilaian dan biaya pengawasan; atau ii) memberikan sejumlah uang tertentu kepada wali sebagai biaya penilaian yang telah dilakukannya dan semua biaya yang diperlukan oleh wali untuk melaksanakan Restoration Plan. ${ }^{47}$ Wali pula dapat mengajukan permintaan untuk mengganti beberapa biaya lainnya seperti biaya penilaian kerugian (assessment costs), biaya pemulihan darurat (emergency restoration), dan bunga dari jumlah ganti rugi (interest on the amounts recoverable). ${ }^{48}$ Dalam hal PRPs tidak memberikan respon dalam jangka waktu tertentu ${ }^{49}$ atau menolak untuk bertanggung jawab atas Restoration Plan yang telah diajukan, wali selanjutnya berwenang untuk mengugat ganti kerugian ke pengadilan. ${ }^{50}$

\section{B. Penerapan Hak Gugat Pemerintah atas Kerugian Lingkungan di Indonesia}

Berdasarkan pada ketentuan Pasal 90 ayat (1) UU PPLH, instansi pemerintah dan pemerintah daerah yang bertanggung jawab di bidang lingkungan berwenang mengajukan gugatan ganti rugi dan tindakan tertentu terhadap usaha dan/atau kegiatan yang menyebabkan pencemaran yang mengakibatkan kerugian lingkungan. Dalam penjelasannya, ganti rugi merujuk pada "kerugian lingkungan hidup" yang merupakan kerugian yang timbul akibat pencemaran yang bukan merupakan hak milik privat. Sementara itu, yang dimaksud dengan "tindakan tertentu" ialah tindakan pencegahan dan penanggulangan pencemaran, serta pemulihan fungsi lingkungan hidup guna menjamin tidak akan terjadi atau terulangnya dampak negatif terhadap lingkungan hidup.

4543 C.F.R. $\S 11.81$ (a) (1); 15 C.F.R. $\S 990.55$ (b) (1).

4615 C.F.R. $\S 990.55$ (b) (2).

4715 C.F.R. $\$ 990.62$ (a) (b); 43 C.F.R. $\$ 11.91$ (a) (b).

48 15 C.F.R. $\S 990.62$ (e) (6).

4915 C.F.R. $\$ 990.64$ (a); 43 CFR $§ 11.91$ (d).

50 DOI's NRDA memberikan $P R P S$ waktu 60 hari terhitung sejak ia menerima surat permintaan yang dikirimkan oleh wali. Sementara itu, NOAA's NRDA mewajibkan PRPS merespon dalam waktu sembilan puluh (90) hari. 
Melalui Peraturan Menteri Lingkungan Hidup Nomor 7 Tahun 2014 tentang Kerugian Lingkungan Hidup Akibat Pencemaran dan/ atau Kerusakan Lingkungan Hidup (Permen Kerugian LH) mengelompokkan kerugian lingkungan hidup dalam empat jenis, antara lain: i) Kerugian karena dilampauinya Baku Mutu Lingkungan Hidup; ii) Kerugian untuk penggantian biaya pelaksanaan penyelesaian sengketa lingkungan hidup; iii) Kerugian untuk pengganti biaya penanggulangan pencemaran dan/atau kerusakan lingkungan hidup serta pemulihan lingkungan hidup; iv) dan Kerugian ekosistem. ${ }^{51}$ Pada Lampiran II Permen Kerugian LH ditambahkan satu jenis kerugian lingkungan lainnya, yakni "biaya kerugian masyarakat akibat pencemaran dan/ atau kerusakan lingkungan hidup". ${ }^{52}$

Pemerintah tercatat secara konsisten menggugat tergugat untuk dua hal. Kedua tuntutan tersebut antara lain: i) membayar kepada penggugat ganti kerugian akibat pencemaran dan/atau kerusakan lingkungan hidup yang telah disebabkannya (ganti rugi atas kerugian ekosistem); dan ii) membayar biaya ganti rugi pemulihan lingkungan hidup (ganti rugi atas biaya pemulihan) atau melakukan pemulihan fungsi lingkungan hidup (dalam hal tergugat yang dihukum oleh pengadilan untuk melakukan pemulihan).

Mengenai yang pertama, pemerintah menentukan besaran kerugian ekosistem berdasarkan dua indikator, yakni: kerugian lingkungan (kerugian ekologis) dan kerugian ekonomi, yang mana keduanya digabungkan sebagai kerugian material. Pemerintah merinci kerugian ekologis, misalnya pada kasus kebakaran lahan gambut, dengan parameter sebagai berikut: penyimpanan air (biaya pembuatan reservoir dan biaya pemeliharaannya), pengaturan tata air, pengendalian erosi, pembentuk tanah, pendaur ulang unsur hara, pengurai limbah, keanekaragaman hayati, sumber daya genetik, pelepasan karbon (carbon release), dan perosot karbon (carbon reduction)..$^{53}$ Sementara itu, terkait dengan kerugian ekonomi terdapat dua parameter yang dipertimbangkan oleh penggugat dalam mengukur besar kerugian ekonomi, yakni hilangnya umur pakai lahan dan keuntungan yang hilang. ${ }^{54}$ Pada beberapa kasus, selain mempertimbangkan kerugian

51 Pasal 3 Permen Kerugian LH.

52 Wibisana menolak dimasukkannya jenis kerugian ini. Hal tersebut didasarkan karena tidak disebutkannya kerugian masyarakat pada Pasal 3 Permen Kerugian LH. Selain itu, berdasarkan Penjelasan Pasal 90 ayat 1 UU PPLH dan Pasal 1 dan 2 dari Permen Kerugian LH, kerugian lingkungan diartikan sebagai kerugian yang timbul akibat pencemaran yang bukan milik privat. Kerugian masyarakat yang ada dalam Lampiran II Permen Kerugian LH bertentangan dengan maknanya dengan definisi kerugian lingkungan yang dimaksudkan oleh UU PPLH dan Permen Kerugian LH. (Lihat catatan kaki pada: Wibisana, op.cit., hlm. 264).

53 Lihat: Putusan Pengadilan Negeri Jakarta Selatan No. 591/Pdt.G-LH/2015/PN.Jkt.Sel. Hlm. 23-25; Putusan Pengadilan Negeri Jakarta Selatan No. 456/Pdt.G-LH/2016/PN.Jkt.Sel. Hlm. 31-34; Putusan Pengadilan Negeri Palembang No. 24/Pdt.G/2015/PN.Plg. Hlm. 13-17; Putusan Pengadilan Negeri Jakarta Selatan No. 700/Pdt.G/2013/PN.Jkt.Sel. Hlm. 28-31; Putusan Pengadilan Negeri Meulaboh No. 12/Pdt.G/2012/PN.MBO. Hlm. 37-43.

54 Ahli perhitungan kerugian lingkungan, Basuki Wasis, menerangkan dalam wawancara yang dilakukan pada tanggal 12 Oktober 2019 bahwa, "Berdasarkan Permen LH Nomor 7 tahun 2014 untuk kerugian ekonomi selain hilangnya umur pakai lahan, ada komponen lain seperti nilai kayu (biomassa), nilai tanah/lahan, nilai material tambang (emas, nikel, bauksit, batubara, besi, tembaga, pasir besi dan lainnya (tambang golongan C) (yang dapat dihitung sebagai kerugian ekonomi)." 
material (kerugian ekologis dan kerugian ekonomi), penggugat dalam perhitungan atas kerugian lingkungan ekosistem memuat pula kerugian tak ternilai atau kerugian immaterial..$^{55}$

Selanjutnya, terkait dengan besaran penggantian atas biaya pemulihan, pemerintah menghitungnya berdasarkan pada biaya riil pemulihan dan metode teoretis. Pada kasus kerusakan lahan gambut akibat kebakaran, pemerintah mengajukan ganti rugi untuk biaya pembelian kompos, pengangkutan, dan penyebarannya. Selain itu, untuk mengaktifkan kembali fungsi ekologis yang hilang akibat lahan gambut yang rusak, pemerintah menuntut biaya pendaur ulang unsur hara, pengurai limbah, keanekaragaman hayati, sumber daya genetik, pelepasan karbon, dan perosot karbon. ${ }^{56}$ Biaya-biaya tersebut dihitung berdasarkan rumus-rumus yang telah baku ditetapkan dalam lampiran Permen Kerugian LH.

\section{Hak Gugat Pemerintah dan Pemulihan Lingkungan: Missing- Link dalam Penerapan Hak Gugat Pemerintah di Indonesia}

Jika dibandingkan dengan pengalaman di AS, penerapan hak gugat pemerintah atas kerugian lingkungan di Indonesia menunjukkan adanya perbedaan mendasar, baik dari sisi teoritis maupun dari sisi praktis. Dari sisi teoretis, hak gugat pemerintah di Indonesia lebih dilihat sebagai upaya untuk memperoleh sejumlah uang ganti rugi, dibandingkan dengan upaya memulihkan kerugian yang timbul karena rusak/ tercemarnya trust corpus. Dari sisi praktis, penghitungan kerugian lingkungan dalam gugatan pemerintah di Indonesia tidak didasarkan atas rencana pemulihan yang layak.

Dua hal inilah yang dapat dianggap sebagai missing-link dalam pelaksanaan hak gugat pemerintah di Indonesia. Keduanya akan dibahas lebih jauh berikut ini.

\section{Persoalan Teoretis: Hak Gugat Pemerintah, Ganti Rugi, dan Kas Negara}

Sampai saat ini, telah terdapat beberapa putusan terkait perusakan/pencemaran yang dimenangkan oleh pemerintah sebagai penggugat. Sebagian besar putusan tersebut merupakan putusan terkait pembalakkan liar dan kebakaran lahan. Tulisan ini mencatat

55 Pada kasus Menteri LH melawan PT. Selatnasik Indokwarsa dan PT. Simpang Pesak Indokwarsa, penggugat (Menteri $L H$ ) mendalilkan bahwa akibat perbuatan tergugat, penggugat menderita kerugian immateriil berupa tudingan dari negara-negara lain bahwa Indonesia sebagai negara perusak hutan tropis yang merupakan paruparu dunia. (Putusan Mahkamah Agung No. 109 PK/Pdt/2014. Hlm. 16). Lihat pula: Kasus KLHK melawan PT. Palmiah Utama (Putusan Pengadilan Negeri Banjarmasin No. 125/Pdt.G/LH/2016/PN.Bjm. Hlm. 42).

56 Lihat: Putusan Pengadilan Negeri Jakarta Selatan No. 591/Pdt.G-LH/2015/PN.Jkt.Sel. Hlm. 175-176; Putusan Pengadilan Negeri Palembang No. 24/Pdt.G/2015/PN.Plg. Hlm. 19-20); Putusan Pengadilan Negeri Banjarmasin No. 125/Pdt.G/2016/PN.Bjm. Hlm. 51; Putusan Pengadilan Negeri Meulaboh No. 12/Pdt.G/2012/ PN.MBO. Hlm. 51; Putusan Pengadilan Negeri Jakarta Selatan No. 456/Pdt.G-LH/2016/PN.Jkt.Sel. Hlm. 45; Putusan Pengadilan Negeri Jakarta Selatan No. 700/Pdt.G/2013/PN.Jkt.Sel. Hlm. 39. 
bahwa beberapa tergugat dalam putusan tersebut telah pula membayar ganti rugi dan biaya melakukan pemulihan. ${ }^{57}$

Uniknya, di Indonesia, tergugat membayarkan ganti rugi dan biaya pemulihan kepada kas negara. ${ }^{58}$ Lebih jauh lagi, paradigma yang berkembang selama ini adalah sebagian uang yang diterima oleh pemerintah (penggugat) dari tergugat adalah sebagai kompensasi atas kerugian negara akibat rusaknya sumber daya alam yang bukan milik privat, yaitu ganti rugi atas kerugian ekosistem yang terdiri dari kerugian ekologi dan kerugian ekonomis. Ahli penghitungan kerugian lingkungan hidup pemerintah, Bambang Hero Saharjo, menyebut bahwa uang ganti rugi atas kerugian ekologis dan ekonomis adalah hak negara karena kerusakan terjadi di atas lahan milik negara sehingga tepat jika dua komponen kerugian tersebut masuk sebagai penerimaan ke kas negara. ${ }^{59}$ Senada dengan itu, Basuki Wasis menjelaskan peruntukkan ganti rugi atas kerugian ekologis (dan pula kerugian ekonomis) sebagai berikut:
"Berdasarkan Permen LH No 7 tahun 2014 kerugian ekologis adalah kerugian negara karena hilangnya komponen ekosistem yang hilang atau musnah, semua kerugian itu (uangnya) harus disetor ke negara dan tidak kembali ke lingkungan yang rusak." 60

Tulisan ini menanggap bahwa paradigma seperti ini bermasalah karena dua alasan. Pertama, pengajuan gugatan ganti kerugian oleh negara seperti ditunjukkan di dalam praktik di AS dan beberapa negara lain, ${ }^{61}$ seharusnya bertujuan untuk memulihkan kerugian yang diderita oleh publik secara utuh akibat rusak dan/atau tercemarnya suatu sumber daya alam. Singkatnya, gugatan pemerintah dilakukan untuk make the public whole. Oleh karena itu, biaya yang didapat oleh wali (trustee) dari si pencemar harus

57 Berdasarkan keterangan Kepala Sub Direktorat Penyelesaian Sengketa Melalui Pengadilan pada Direktorat Jenderal Penegakan Hukum Kementerian Lingkungan Hidup dan Kehutanan dalam wawancara yang dilakukan pada tanggal 31 Sepetember 2019, pihak tergugat yang telah membayar ganti rugi atas kerugian ekosistem PT. Bumi Mekar Hijau. Pengadilan memerintahkan PT. Bumi Mekar Hijau membayar ganti rugi kepada penggugat (pemerintah) sebesar Rp.78.502.500.000,-. Lihat: Putusan Pengadilan Tinggi Palembang No. 51/PDT/2016/ PT.PLG. Hlm. 190. Dalam keterangan tersebut dinyatakan juga bahwa PT. Selatnasik Indokwarsa dan PT. Simpang Pesak Indokwarsa adalah pihak tergugat lainnya yang telah melakukan pembayaran ke Kas Negara. Berdasarkan putusan pengadilan, PT. Selatnasik Indokwarsa dan PT. Simpang Pesak Indokwarsa diharuskan membayar biaya pemulihan lingkungan dengan nilai total sebesar Rp.32.264.312.000,-. Lihat: Putusan Mahkamah Agung No. 109 PK/Pdt/2014. Hlm. 38-39.

$58 \mathrm{Hal}$ ini sesusai dengan apa yang diperintahkan oleh pengadilan. Lihat: Putusan Pengadilan Negeri Jakarta Selatan No. 456/Pdt.G-LH/2016/PN.Jkt.Sel. Hlm. 304; Putusan Mahkamah Agung No. 690 PK/Pdt/2018. Hlm. 13; Putusan Pengadilan Tinggi Banda Aceh No. 50/PDT/2014/PT.BNA. Hlm. 62. Lihat pula: Pasal 8 ayat (1) Permen Kerugian LH.

59 Wawancara dengan Bambang Hero Saharjo, Ahli penghitungan kerugian lingkungan hidup KLHK dan Guru Besar pada Fakultas Kehutanan IPB, 8 November 2019.

60 Wawancara melalui email dengan Basuki Wasis, Ahli penghitungan kerugian lingkungan hidup KLHK dan Akademisi pada Fakultas Kehutanan IPB, 12 Oktober 2019.

61 Untuk diskusi singkat mengenai gugatan kerugian oleh Pemerintah di Eropa, lihat misalnya: Wibisana, op.cit., hlm. 262-264. 
digunakan seluruhnya untuk melakukan pemulihan lingkungan yang rusak dan/ atau tercemar serta segala kepentingan yang berkaitan dengan itu. Kewajiban tersebut dinyatakan dengan tegas dalam OPA dan CERCLA di AS. ${ }^{62}$

Kedua, negara bukanlah pemilik sumber daya yang bukan milik privat (sungai, hutan lindung, pantai, laut, hewan-hewan di alam liar), sehingga pada hakikatnya negara tidak mempunyai kepentingan untuk mengajukan gugatan atas kerugian yang timbul darinya. Di AS dan pula secara umum di negara lain, lingkungan yang bukan milik privat atau public natural resources adalah kepunyaan publik. ${ }^{63}$ Dua doktrin yang lazim dirujuk untuk menerangkan standing negara dalam klaim atas kerugian lingkungan, yakni doktrin public trust dan parens patriae, pun tegas menolak bahwa dasar pemerintah dapat mengajukan gugatan atas kerugian akibat rusak dan/atau tercemarnya suatu sumber daya tertentu adalah karena dasar kepemilikan negara atas sumber daya tersebut. Tindakan pemerintah itu dilakukan atas nama kepentingan umum (on behalf of all citizens). ${ }^{64}$ Status sebagai trustee atau wali mewajibkan negara untuk menjamin dan memberikan perlindungan terhadap lingkungan sebagai upaya untuk menyelenggarakan kesejahteraan bagi warga negaranya.

Dalil "dikuasai oleh negara" sebagaimana dalam Pasal 33 ayat (3) Undang-Undang Dasar Negara Republik Indonesia Tahun 1945 (UUD NRI Tahun 1945), yang dijadikan sebagai landasan kedudukan pemerintah sebagai penggugat dalam sengketa lingkungan di Indonesia ${ }^{65}$ tidak dapat dimaknai sebagai bukti bahwa pemerintah mempunyai hak kepemilikan atas lingkungan yang bukan milik privat sehingga memungkinkan bagi negara untuk menerima kompensasi atas kerugian terhadap lingkungan dalam bentuk penerimaan negara ${ }^{66}$ Mahkamah Konstitusi

6242 U.S.C. 99607 (f) (1); 33 U.S.C. § 2706 (f).

63 Berdasarkan hukum Romawi, benda (things or goods) diklasifikasikan dalam "yang dapat dimiki oleh seseorang (those belonging to someone)" dan "yang terbuka bagi setiap orang (those open to everyone)". Kelompok pertama adalah kepemilikan privat, yang dapat diperjual-belikan atau diwariskan. Sedangkan kelompok kedua adalah segala sesuatu yang tidak terkategori pada kelompok pertama, misalnya kuil yang dianggap sebagai milik Tuhan, bangunan umum yang dipunyai oleh negara, dan benda-benda yang disebut sebagai res nullius dan res communis. Benda-benda yang diklasifikasikan sebagai res nullius tidak dapat dimiliki oleh siapapun, tetapi mereka dapat menjadi objek kepemilikan, contohnya hewan-hewan liar dan ikan di aliran sungai yang dapat dimiliki oleh seseorang dengan menangkapnya. Sementara itu, benda-benda yang terkategori sebagai res communis adalah segala sesuatu yang secara alami tidak dapat tunduk pada kepemilikan individu, misalnya udara, sungai, dan laut. Mereka digunakan dan dinikmati oleh setiap orang dan tidak dapat dimiliki (atau setidaknya tidak secara keseluruhan). (Brans, op.cit., pp. 36-37).

64 Deborah G. Musiker et.al., "The Public Trust and Parens Patriae Doctrines: Protecting Wildlife in Uncertain Political Times," Public Land and Resources Law Review 16, No. 87 (1995): 94, 104.

65 Putusan Pengadilan Negeri Banjarmasin No. 125/Pdt.G/2016/PN.Bjm. Hlm. 3; Putusan Pengadilan Negeri Palembang No. 24/Pdt.G/2015/PN.Plg. Hlm. 2; Putusan Pengadilan Negeri Jakarta Selatan No. 456/Pdt.GLH/2016/PN.Jkt.Sel. Hlm. 3; Putusan Pengadilan Negeri Meulaboh No. 12/PDT.G/2012/PN.MBO. Hlm. 3-4; Putusan Pengadilan Negeri Jakarta Selatan No. 700/Pdt.G/2013/PN.Jkt.Sel. Hlm. 2; Putusan Pengadilan Negeri Jambi No. 107/Pdt.G/LH/2019/PN.Jmb. Hlm. 2-3.

66 Faktanya, dalil bahwa kerugian lingkungan merupakan bagian daripada kerugian negara tidak hanya dipahami dalam lingkup keperdataan, melainkan telah pula diterapkan pada ranah hukum pidana sebagaimana yang dilakukan oleh Jaksa Penuntut Umum Komisi Pemberantasan Korupsi (KPK) manakala mendakwa Gubernur Sulawesi Utara, Nur Alam, telah melakukan tindak pidana korupsi karena mengakibatkan kerugian negara yang berasal dari musnahnya atau berkurangnya ekologis/lingkungan. (Putusan Pengadilan Negeri Jakarta Pusat No. 123/Pid.Sus/2017/PN Jkt.Pst. Hlm. 67-68). 
dalam putusannya telah menerangkan konsep “dikuasai oleh negara" adalah sesuatu yang lebih tinggi dari pemilikan. ${ }^{67}$

Lebih dari itu, di Indonesia tidak ada pembedaan yang tegas antara pemulihan primer/utama (primary restoration) dan pemulihan atas kerugian sementara (compensatory restoration). Barangkali biaya pemulihan yang diajukan oleh pemerintah dalam gugatannya dapat dipadankan dengan primary restoration cost karena keduanya ditujukan untuk membiayai kegiatan pemulihan atas sumber daya alam yang rusak/tercemar sehingga kembali ke kondisi dasarnya. Akan tetapi, keraguan muncul untuk menyamakan antara ganti rugi atas kerugian ekosistem (kerugian ekologis dan kerugian ekonomi) yang dituntutkan oleh pemerintah Indonesia dengan compensatory restoration cost atau compensable value sebagaimana yang dipahami di AS. Keraguan itu didasari oleh beberapa alasan yang dijelaskan sebagai berikut.

Pertama, dari praktik yang ada, kerugian ekologis dan ekonomis di Indonesia tampak memiliki tujuan yang berbeda dari compensable value di AS. Compensatory restoration cost atau compensable value ditujukan untuk mengganti kerugian publik atas hilangnya jasa lingkungan akibat rusak/ tercemarnya sumber daya alam, yang dihitung sejak mula terjadinya kerusakan/pencemaran pada lingkungan/sumber daya alam sampai dengan pulihnya kondisi lingkungan/sumber daya alam seperti semula atau sampai digantikannya lingkungan/sumber daya alam yang rusak tersebut. Sementara itu, apabila merujuk pada paradigma yang berkembang sebagaimana telah dijelaskan sebelumnya, tujuan biaya ganti rugi atas kerugian ekosistem di Indonesia adalah dianggap sebagai kompensasi atas kerugian negara, sehingga tidak ada keharusan untuk menggunakan ganti kerugian bagi pemulihan lingkungan atas daerah yang diklaim telah mengalami kerusakan.

Kedua, antara compensatory restoration cost atau compensable value dan biaya ganti rugi atas kerugian ekosistem berbeda pula jika ditinjau dari detail penghitungannya. Di AS, Penentuan pemulihan atas kerugian sementara (interim losses) yang pada akhirnya menentukan besaran compensatory restoration cost atau compensable value melalui proses/ tahapan yang ketat. Wali diharuskan memprioritaskan pendekatan "resource-toresource" atau "service-to-service", yaitu pendekatan untuk menghasilkan sumber daya (resource) atau jasa (service) dengan kuantitas yang setara (equal) dengan sumber daya atau jasa yang hilang. ${ }^{68}$ Jika pendekatan ini tidak dapat dilakukan, maka wali baru boleh memilih prioritas kedua, yaitu pendekatan valuasi, yang terdiri dari pendekatan "valueto-value" dan pendekatan "value-to-cost". Dalam pendekatan ini, wali menentukan 
jumlah sumber daya atau jasa yang harus disediakan untuk menghasilkan nilai yang hilang karena insiden. ${ }^{69}$

Sekilas penghitungan ganti rugi atas kerugian ekosistem (kerugian ekologis dan kerugian ekonomis) yang dituntutkan oleh pemerintah Indonesia dalam gugatannya mirip dengan penghitungan compensable value dengan pendekatan "value-to-cost" di AS, yakni pendekatan yang menekankan bahwa nilai interim losses akibat adanya insiden digantikan dengan pemulihan yang biayanya setara dengan nilai yang hilang tersebut. $^{70}$ Persoalannya, penghitungan "value" dari kerugian lingkungan, baik melalui pendekatan "value-to-value" maupun "valueto-cost", dilakukan dengan menggunakan metode-metode pengitungan yang valid dan memiliki landasan ilmiah yang diakui, seperti Contingent valuation (CV), Travel cost, Hedonic pricing, dan lain-lain. ${ }^{71}$ Tidak jelas apakah bagaimana metode-metode tersebut digunakan dalam penghitungan biaya ganti rugi atas kerugian ekosistem oleh pemerintah Indonesia sebagaimana tertera di dalam PerMen LH atau gugatan-gugatannya.

\section{Persoalan Praktis: Gugatan Ganti Rugi Tanpa Pemulihan}

Tulisan ini melihat bahwa paradigma yang melihat ganti rugi sebagai upaya untuk menambah penghasilan negara dari ganti kerugian lingkungan, pada akhirnya akan sejalan dengan munculnya persoalan praktis dalam hak gugat pemerintah di Indonesia. Pertama, penghitungan kerugian tidak didasarkan pada biaya riil yang dikeluarkan untuk pemulihan yang telah dilakukan. Jika pemulihan belum dilakukan, maka penghitungan ganti rugi juga tidak didasarkan pada rencana pemulihan yang jelas.

Indonesia tidak mengenal konsep Restoration Plan. Di AS, penyusunan Restoration Plan dilakukan melalui tahapantahapan yang ketat dan harus terbuka bagi publik dan diinformasikan kepada pihak pencemar. Restoration Plan ini yang akan menjadi dasar "tagihan" oleh Pemerintah selaku wali dari trust corpus yang mengalami kerusakan/pencemaran dapat dipertanggungjawabkan, baik secara ekonomis maupun ekologis. Sementara di Indonesia, proses seperti ini tidak terjadi. Menganggap beberapa lembar dari posita gugatan pemerintah yang berisi perhitungan kerugian sebagai Restoration Plan adalah tidak tepat. Hal ini karena Pemerintah tidak secara rinci menjelaskan bagaimana kerugian ini akan dipulihkan, dengan cara seperti apa, dan berapa lama.

Sebagian besar komponen kerugian dihitung berdasarkan rumus-rumus yang telah baku ditetapkan dalam lampiran PerMen Kerugian LH. Di dalam kasus kebakaran lahan atau pembalakan liar, misalnya, 
komponen biaya ini biasanya terdiri dari biaya pendaur ulang unsur hara, pengurai limbah, keanekaragaman hayati, sumber daya genetik, pelepasan karbon, dan perosot karbon (untuk mengaktifkan kembali fungsi ekologis yang hilang). ${ }^{72}$ Persoalannya, PerMen LH ini tidak memberikan kepastian bagaimana kerugian lingkungan yang terjadi akan dikembalikan ke kondisi awal (baseline).

Kedua, cara penghitungan kerugian yang tidak didasarkan pada pengeluaran untuk pemulihan yang nyata, baik yang telah dilakukan ataupun yang belum dilakukan, yang didasarkan pada penggunaan metode penghitungan teoretis-hipotesis. Persoalan dari metode ini adalah adanya peluang yang cukup besar bahwa pemerintah akan meminta sejumlah uang untuk ganti rugi biaya pemulihan, dan kemudian memperoleh ganti rugi tersebut, meskipun pada kenyataannya tidak pernah melakukan tindakan pemulihan atau merencanakan untuk melakukan pemulihan tersebut. ${ }^{73}$ Kondisi demikian itu telah terjadi di Indonesia, di mana penggugat belum kunjung melakukan pemulihan terhadap lingkungan yang rusak dalam kasus PT. Selatnasik Indokwarsa dan PT. Simpang
Pesak Indokwarsa dan PT. Bumi Mekar Hijau meskipun ganti rugi untuk melakukan pemulihan telah tuntas dibayarkan oleh tergugat. $^{74}$

Uniknya, PerMen LH memungkinkan pemerintah untuk mengklaim bahwa metode penghitungan kerugian yang digunakan telah berdasarkan pada biaya riil. Misalnya, dalam kasus kebakaran lahan gambut, PerMen LH menulis pemulihan untuk biaya pembelian kompos, biaya pengangkutan, dan penyebarannya di lahan yang terbakar sebagai upaya pemulihan atas gambut yang rusak. Tanpa adanya rencana pemulihan, klaim seperti ini dapat menimbulkan perdebatan, seperti dalam KLHK melawan PT. National Sago Prima. Dalam kasus ini, tergugat menilai tidaklah logis pemulihan dilakukan dengan penambahan sisa bahan organik (kompos) pada sisa bahan hasil pelapukan (weathering) bahan organik (gambut). Selain itu, tergugat berdalih bahwa pemulihan dengan kompos tersebut mustahil dilaksanakan karena tidak ada ketersediaan kompos dalam jumlah sedemikan besar untuk ditaburkan pada lahan gambut seluas \pm 3000 hektar. ${ }^{75}$ Dalih tergugat seperti ini dapat dibantah dengan mudah

72 Putusan Pengadilan Negeri Meulaboh No. 12/Pdt.G/2012/PN.MBO. Hlm. 37-44; Putusan Pengadilan Negeri Jakarta Selatan No. 456/Pdt.G-LH/2016/PN.Jkt.Sel. Hlm. 31-36; Putusan Pengadilan Negeri Jakarta Selatan No. 591/Pdt.G-LH/2015/PN.Jkt.Sel. Hlm. 23-26; Putusan Pengadilan Negeri Jambi No. 107/Pdt.G/LH/2019/ PN.Jmb. Hlm. 13-24.

73 A.G. Wibisana dan T.A. Dewaranu, "Environmental damage and liability in Indonesia: Fancy words under conventional wisdom," in Law and Justice in a Globalized World, ed. oleh Harkristuti Harkrisnowo, Hikmahanto Juwana, dan Yu Un Oppusunggu (London: Routledge, 2018), pp. 221-222.

74 Menurut keterangan Kepala Sub Direktorat Penyelesaian Sengketa Melalui Pengadilan pada Direktorat Jenderal Penegakan Hukum Kementerian Lingkungan Hidup dan Kehutanan dalam wawancara yang dilakukan pada tanggal 31 September 2019, pemulihan belum dilakukan oleh penggugat (pemerintah) disebabkan oleh belum adanya regulasi yang mengatur mengenai mekanisme pencairan dana pemulihan yang telah disetor ke Kas Negara.

75 Putusan Pengadilan Negeri Jakarta Selatan No. 591/Pdt.G-LH/2015/PN.Jkt.Sel. Hlm. 175. 
seandainya klaim pemerintah di dalam gugatan didasarkan pada rencana pemulihan yang nyata atau dengan benar-benar melakukan tindakan pemulihan.

\section{Usulan untuk Mengatasi Missing- Link}

Kedua missing-link dalam praktik hak gugat pemerintah di Indonesia bukanlah sesuatu yang tidak dapat diperbaiki. Tulisan ini melihat ada beberapa kemungkinan perbaikan, mulai dari hal yang paling mendasar sampai pada hal perubahan praktis.

Pertama, dalam kondisi ideal, tulisan ini melihat kebutuhan mendesak perbaikan atas ketentuan yang berkaitan dengan hak gugat pemerintah. Sebaiknya perbaikan tersebut memuat ketentuan bahwa pemerintah hanya dapat meminta ganti rugi untuk mengganti biaya penanggulangan dan pemulihan pencemaran yang telah atau akan dilakukan. Konsekuensinya, diperlukan adanya prosedur bagi pelaksanaan penanggulangan dan pemulihan, yang kemudian akan mewajibkan pula bagi pemerintah untuk menyiapkan rencana pemulihan (restoration plan). Keberadaan prosedur yang detail untuk penilaian kerugian, termasuk prosedur penyusunan rencana pemulihan, adalah hal yangutamadanjauhlebihpentingdibandingkan dengan rumus-rumus penghitungan kerugian untuk parameter tertentu, yang justru sering kali dipertanyakan validitasnya. Singkatnya, tidak ada gugatan untuk kerugian lingkungan tanpa adanya rencana pemulihan lingkungan.
Kedua, sambil mengunggu perbuahan peraturan perundangan-undangan terkait mekanisme hak gugat pemerintah, terhadap kasus-kasus yang sedang diajukan oleh pemerintah, pengadilan dapat meminta agar setiap gugatan pemerintah atas kerugian lingkungan harus menyertakan rencana pemulihan yang akan dilakukan. Ketiga, untuk kasus yang telah berkekuatan hukum tetap, pengadilan dapat mensyaratkan bahwa eksekusi hanya dapat dilakukan jika pemerintah menunjukkan rencana pemulihan yang akan dilakukannya.

Usulan kedua dan ketiga ini perlu disampaikan untuk memastikan bahwa gugatan pemerintah tidak akan dijadikan sekedar tempat bagi pemerintah untuk menambah kas negara. Sebaliknya, usulan tersebut disampaikan guna memastikan bahwa pemulihan akan dilakukan, dengan biaya yang ditanggung oleh pencemar (tergugat).

\section{Simpulan}

Pemulihan atas kerugian pada dasarnya menekankan pada pencapaian tujuan pokok, yakni "to make the public whole". Pemulihan kerugian lingkungan pula harus dilakukan melalui tahapan-tahapan yang ketat, yang pada akhirnya menghasilkan dokumen rencana pemulihan (restoration plan) yang menjadi dasar bagi setiap pihak yang dibenakan tugas untuk melaukan pemulihan terhadap lingkungan yang rusak dan/atau tercemar

Manakala disandingkan dengan penerapan hak gugat pemerintah atas kerusakan 
lingkungan diAS, terdapat beberapa perbedaan mendasar dengan praktek yang berlaku di Indonesia. Pertama, pemerintah Indonesia (KLHK) sebagai wali tidak membuat rencana pemulihan yang detail menjelaskan bagaimana pemulihan terhadap lingkungan yang rusak akan dilakukan sebagaimana Restoration Plan di AS. Kedua, pemerintah Indonesia (KLHK) dalam melakukan perhitungan terhadap kerugian lingkungan terpaku pada format/contoh yang dimuat dalam lampiran Permen Kerugian LH. Hal ini berbeda dari AS yang melakukan penghitungan kerugian lingkungan secara spesifik terhadap suatu sumber daya yang rusak (bersifat kasuistis) dengan tahapan-tahapan yang ketat.

Ketiga, di Indonesia tidak ada pembedaan yang tegas antara pemulihan primer/utama (primary restoration) dan pemulihan atas kerugian sementara (compensatory restoration). Biaya pemulihan yang diajukan oleh pemerintah dalam gugatannya dapat dipadankan dengan primary restoration cost karena keduanya ditujukan untuk membiayai kegiatan pemulihan atas sumber daya alam yang rusak/tercemar sehingga kembali ke kondisi dasarnya. Akan tetapi, keraguan muncul untuk menyamakan antara ganti rugi atas kerugian ekosistem (kerugian ekologis dan kerugian ekonomi) dengan compensatory restoration cost atau compensable value sebagaimana yang dipahami di AS karena tujuan biaya ganti rugi atas kerugian ekosistem di Indonesia yang dianggap sebagai kompensasi atas kerugian negara dan tidak dikembalikan kepada lingkungan untuk maksud pemulihan, padahal dalam praktek di AS compensatory restoration cost atau compensable value ditujukan untuk mengganti kerugian publik atas hilangnya jasa lingkungan akibat rusak/tercemarnya sumber daya alam, yang dihitung sejak mula terjadinya kerusakan/pencemaran pada lingkungan/ sumber daya alam sampai dengan pulihnya kondisi lingkungan/sumber daya alam seperti semula atau sampai digantikannya lingkungan/ sumber daya alam yang rusak tersebut. Selain itu, jika pendekatan yang dilakukan bukanlah "resource-to-resource" atau "service-toservice," pemulihan kerugian sementara (interim losses) di AS dilakukan dengan menggunakan metode-metode penghitungan yangmemiliki landasan pembenaran teoretis yang teruji, seperti Contingent valuation (CV), Travel cost, Hedonic pricing, dan lainlain. Pendekatan dan metode penghitungan mana yang diterapkan di Indonesia, ternyata tidaklah jelas.

Untuk menjamin kembalinya fungsi gugatan pemerintah ke fungsi asalnya, dan untuk memastikan adanya pemulihan bagi lingkungan yang rusak, maka perlu ada perbaikan dalam penerapan hak gugat pemerintah. Tidak ada gugatan pemerintah tanpa pemulihan. Pemulihan ini harus dijelaskan di dalam rencana pemulihan, baik di dalam gugatan maupun dalam rangka eksekusi putusan. 


\section{DAFTAR PUSTAKA}

\section{Buku}

Brans, Edward H.P. Liability for Damage to Public Natural Resources: Standing, Damage and Damage Assessment. The Hague: Kluwer Law International, 2001.

Gray, Peter L. The Superfund Manual: A Practitioner's Guide to CERCLA Litigation. Chicago: ABA, 2016, p. 297 Wibisana, Andri G. Penegakan Hukum Lingkungan Melalui Pertanggungjawaban Perdata. Depok: BP-FHUI, 2017.

\section{Kumpulan Tulisan dalam Buku}

Faure, Michael et.al. "Economic instruments : suited to developing countries?" In Environmental Law in Development: Lessons from the Indonesian Experience, edited by Michael Faure and Nicole Niessen. Cheltenham: Edward Elgar Publishing, 2006. pp. 222-224.

Phelps, Jacob et.al. "Liability for Environmental Harm as a Response to the Anthropocene." In Charting Environmental Law Futures in the Anthropocene, edited by Michelle Lim. Singapore: Springer, 2019. p. 173.

Wibisana, A.G. dan T.A. Dewaranu. "Environmental damage and liability in Indonesia: Fancy words under conventional wisdom." In Law and Justice in a Globalized World, diedit oleh Harkristuti Harkrisnowo, Hikmahanto Juwana, dan Yu Un Oppusunggu. London: Routledge, 2018. pp. 221-222.

\section{Jurnal}

Burlington, Linda B. "Valuing Natural Resource Damages: A Transatlantic Lesson". Environmental Law Review 6, No. 2 (2004): 78-81.

Faure, Michael and Jing Liu. "New Models For The Compensation Of Natural Resources Damage". Kentucky Journal for Equine, Agriculture, and Natural Resources Law 4, No. 2 (2012): 269.

Jing, Liu et.al., "Compensating for Natural Resource Damage Caused by VesselInduced Marine Oil Pollution: Comparing the International, U.S., and Chinese Regimes". Journal of Environmental Law \& Litigation 29 (2014): 150-151.

Jones, Carol A. and Katherine A. Pease. "Restoration-Based Compensation Measures in Natural Resource Liability Statutes". Contemporary Economic Policy15 (October 1997): 111-122.

Jones, Carol Adaire and Lisa DiPinto. "The Role of Ecosystem Services in USA Natural Resource Liability Litigation”. Ecosystem Services 29 (2018): 336. 
Jones, Carol Adaire et al. "Tropical Conservation and Liability for Environmental Harm". Environmental Law Review 45, No. 1 (2015): 1035. Jones, Carol Adaire. "Economic Valuation of Resource Injuries in Natural Resource Liability Suits," Journal of Water Resources Planning and Management 126, No. 6 (2000): 358.

Kanner, Allan and Mary E. Ziegler, "Understanding and Protecting Natural Resources". Duke Environmental Law \& Policy Forum 17, No. 119 (2006): 147.

Kanner, Allan. "Natural Resource Restoration". Tulane Environmental Law Journal 28, No. 1 (2015): 5.

Bradshaw, Karen. "Settling for Natural Resource Damages". Harvard Environmental Law Review, Vol. 40, (2016): 219.

Mazzotta, Marisa J. et.al. "Natural Resource Damage Assessment: The Role of Resource Restoration". Natural Resources Journal, Vol. 34 (Winter 1994): 168.

Musiker, Deborah G. et.al., "The Public Trust and Parens Patriae Doctrines: Protecting Wildlife in Uncertain Political Times," Public Land and Resources Law Review 16, No. 87 (1995): 94, 104.

Ofiara, Douglas D. "Natural Resource Damage Assessments in the United States: Rules and Procedures for Compensation from Spills of Hazardous Substances and Oil in Waterways under US Jurisdiction". Marine Pollution Bulletin 44, No. 2 (2002): 100.

Snyder, Joan P. and William H. Desvousges, "Habitat and Resource Equivalency Analyses in Resource Compensation and Restoration Decision Making". Natural Resources \& Environment 28 (Summer 2013): 3-7.

Strickland, Carter H. "The Scope of Authority of Natural Resource Trustees". Colombia Journal of Environmental Law 20, No. 1 (1995): 301-327.

Peraturan Perundang-undangan dan Putusan Pengadilan Indonesia

Undang-Undang Nomor 4 Tahun 1982 tentang Ketentuan-ketentuan Pokok Pengelolaan Lingkungan Hidup.

Undang-Undang Nomor 23 Tahun 1997 tentang Pengelolaan Lingkungan Hidup.

Undang-Undang Nomor 32 Tahun 2009 tentang Perlindungan dan Pengelolaan Lingkungan Hidup.

Peraturan Menteri Lingkungan Hidup Nomor 7 Tahun 2014 tentang Kerugian Lingkungan Hidup Akibat Pencemaran dan/atau Kerusakan Lingkungan Hidup.

Peraturan Ketua Mahkamah Agung Nomor 036/KMA/2013 tentang .Pemberlakuan Pedoman Penanganan Perkara Lingkungan Hidup.

Putusan Mahkamah Konstitusi Nomor 001-021-022/PUU-I/2003 tentang Permohonan Pengujian Undang- 
Jonaidi, Wibisana, Konsep Gugatan Pemerintah atas Pencemaran Lingkungan: Komparasi...

undang Nomor 20 Tahun 2002 tentang Ketenagalistrikan terhadap UUD NRI

Tahun 1945, tanggal 21 Desember 2004.

Putusan Mahkamah Agung Republik Indonesia Nomor 109 PK/Pdt/2014 tentang Peninjauan Kembali terhadap Sengketa Lingkungan Hidup antara Menteri Lingkungan Hidup melawan PT. Selatnasik Indokwarsa dan PT. Simpang Pesak Indokwarsa, tanggal 23 Mei 2014.

Putusan Mahkamah Agung No. 690 PK/ Pdt/2018 tentang Menteri Lingkungan Hidup melawan PT. Surya Panen Subur, tanggal 17 Oktober 2018.

Putusan Pengadilan Tinggi Palembang Nomor 51/PDT/2016/PT.PLG tentang Menteri Lingkungan Hidup melawan PT. Bumi Mekar Hijau, tanggal 10 Agustus 2016. Putusan Pengadilan Tinggi Banda Aceh No. 50/PDT/2014/PT.BNA tentang PT. Kallista Alam melawan Menteri Lingkungan Hidup, tanggal 15 Agustus 2014.

Putusan Pengadilan Negeri Jakarta Selatan Nomor 591/Pdt.G-LH/2015/PN.Jkt. Sel tentang Kementerian Lingkungan Hidup dan Kehutanan melawan PT. National Sago Prima, tanggal 1 Agustus 2016.

Putusan Pengadilan Negeri Jakarta Selatan Nomor 456/Pdt.G-LH/2016/PN.Jkt. Sel tentang Kementerian Lingkungan Hidup dan Kehutanan melawan PT.
Waringin Agro Jaya, tanggal 7 Februari 2017.

Putusan Pengadilan Negeri Palembang No. 24/Pdt.G/2015/PN.Plg. tentang Menteri Lingkungan Hidup melawan PT. Bumi Mekar Hijau, tanggal 30 Desember 2015.

Putusan Pengadilan Negeri Jakarta Selatan Nomor $\quad$ 700/Pdt.G/2013/PN.Jkt.Sel tentang Menteri Lingkungan Hidup melawan PT. Surya Panen Subur, tanggal 25 September 2014.

Putusan Pengadilan Negeri Meulaboh Nomor 12/Pdt.G/2012/PN.MBO tentang Menteri Lingkungan Hidup melawan PT. Kallista Alam, tanggal 28 November 2013.

Putusan Pengadilan Negeri Banjarmasin Nomor 125/Pdt.G/2016/PN.Bjm tentang Kementerian Lingkungan Hidup dan Kehutanan melawan PT. Palmina Utama, tanggal 21 Februari 2018 .

Putusan Pengadilan Negeri Jambi Nomor 107/Pdt.G/LH/2019/PN.Jmb tentang Kementerian Lingkungan Hidup dan Kehutanan melawan PT. Agro Tumbuh Gemilang Abadi, tanggal 8 April 2020. Putusan Pengadilan Negeri Jakarta Pusat Nomor 123/Pid.Sus-TPK/2017/PN.Jkt. Pst tentang Tindak Pidana Korupsi dengan Terdakwa Nur Alam, tanggal 28 Maret 2018.

Peraturan Perundang-undangan dan Putusan Pengadilan Negara Asing 
Comprehensive Environmental Response, State of Ohio v. DOI, 880 F.2d 432, 463 (D.C. Compensation, and Liability Act) dan Cir. 1989).

OPA (Oil Pollution Act (CERCLA).

Oil Pollution Act (OPA).

\section{Naskah Internet}

The U.S. Department of the Interior's NOAA, "Scaling Compensatory Restoration Natural Resource Damage Assessment Regulations (DOI's NRDA).

Actions Guidance Document for Natural Resource Damage Assessment

The National Oceanic and Atmospheric Under the Oil Pollution Act of Administration 's Natural Resource 1990". http://www.losco.state.la.us/ Damage Assessment Regulations (NOAA'S NRDA). pdf_docs/NOAA_NRDA_Guidance_ Scaling_1997.pdf. Diakses pada Februari 2021. 